\title{
A whetstone from south-east England at Newstead, Melrose (Trimontium): the reach of a major Roman stone industry
}

\author{
J R L Allen ${ }^{1}$
}

\begin{abstract}
James Curle found at Newstead near Melrose an unusual whetstone of bar-shaped design, with rebates on the long edges, that is now on public display at the National Museum of Scotland (Edinburgh). It is made from a greenish-grey, calcareous, very fine-grained sandstone, attributable to sandstones in the Weald Clay Formation (Lower Cretaceous) outcropping in the Weald of south-east England. Carefully manufactured whetstones produced by a large business in this area occur throughout most of Roman Britain and are also found on the coastal mainland of north-west Europe. The Newstead example is the northernmost of its products known on a spatially exponential distribution of sites.
\end{abstract}

\section{INTRODUCTION}

The legions that invaded Scotland during the early Roman campaigns exploited both western and especially eastern coastal routes. The advance into the south-east Borders along the eastern line took them from York and Corbridge, below Hadrian's Wall, along the route to the Firth of Forth known as Dere Street. At the strategic crossing of the upper River Tweed at Newstead, Melrose, numerous fortified camps and forts (Trimontium) were established and which have long attracted archaeological attention. James Curle in particular excavated this rich site (Curle 1911) and research on it has continued to the present day (Hunter \& Keppie 2012).

In his account Curle did not provide the catalogue of finds that has become conventional in archaeological reports, but tended to record items context-by-context. From his Pit LXI, plausibly Flavian in date, he reported and illustrated an unusual bar-shaped whetstone (Curle 1911: pl LXII), now exhibited at the National Museum of Scotland (Edinburgh), along with scythes and other tools, as an agriculturally significant item (SF FRA 319). Curle's photograph of this puzzling whetstone is too small to show any details and he has nothing to say about the item, except to compare it (Curle 1911: 285) with the associated whetstones of the 'found' type (Allen 2014: 7), fragments of rock suitable in lithology, size and shape, collected from such as fields, river beds and beaches.

The purpose of the present note is to give a modern description of Curle's enigmatic whetstone, to point out its likely provenance in south-east England, and to position it within the known distribution of whetstones from the same source in Roman Britain and north-west Europe.

\section{CHARACTER AND PROVENANCE OF THE WHETSTONE}

The whetstone (Illus 1A) is bar-shaped, measuring $295 \mathrm{~mm}$ in length between the broken ends, just short of a Roman foot and, when stood on a long, narrow face, is seen to be perceptibly curved overall. It is rectangular in cross-section (W: 25-7mm, Th: 14-17mm), widening and

\footnotetext{
${ }^{1}$ Department of Archaeology, University of Reading, School of Archaeology, Geography and Environmental Sciences, Wager Building, Reading RG6 6AB
} 
thickening slightly toward what appears to be the most worn end. Three of the long edges at the opposite, less worn, slightly narrower and thinner end of the bar carry traces of rectangular rebates, the longest survivor of which measures $82 \mathrm{~mm}$.

The item under the hand-lens is composed of a greenish-grey, very fine- to fine-gained quartz sandstone with an abundant white, apparently calcareous matrix. There is also shell debris, including occasional pelecypods and gastropods. The rock is very slightly micaceous and has a scattering of soft, black particles, larger than the associated quartz sand, taken to be carbonaceous (?charcoal). The sandstone exhibits delicate laminations on a sub-millimetre scale, in a plane parallel with the bar in its most stable position. The rock is strong and compact, the bar, when suspended from one end and lightly struck, emitting a musical note.

The Newstead whetstone has all of the handspecimen characteristics reported from widely distributed whetstones ascribed to sandstones present in the early Cretaceous Weald Clay Formation of the north-west Weald in southeast England (Allen 2014; Allen \& Scott 2014). Bar an examination in thin-section under the petrographic microscope, it can be confidently attributed to this source. As illustrated by well-preserved finds at sites such as Fiskerton (Field \& Parker Pearson 2003), Silchester (Allen 2014), Tackley (Shaffrey \& Allen 2014) and Wroxeter (Atkinson 1942; Allen \& Scott 2014), these whetstones are bar-shaped, with rebates on the long edges, about a Roman foot in length, and composed of greenish-grey, very fine- to medium-grained calcareous sandstones with variable amounts of shell debris, mica and carbonaceous grains. The latter, under the optical and scanning electron microscopes, prove to be carbonised wood and charcoal with definite anatomical structure. A very light scattering of glauconite - no more than a few rounded grains per thin-section - is also evident microscopically, and the calcareous matrix is a mixture of finegrained bioclastic debris and crystalline calcite. Large fossil shells are very occasional. A delicate planar to very slightly curved lamination is commonly seen, and is especially well developed at Wroxeter (Allen \& Scott 2014). The rocks used are fresh, strong and compact, and the bars are acoustic, emitting a clear musical note when suspended and struck.

The Newstead whetstone, with its bar shape and longitudinal, rectangular rebates, is clearly of the crafted sort (Allen 2014: 9-13). For Curle (1911: 285) 'It is evidently a carefully manufactured article, unlike the flattened river stones, many of which, it is apparent, had been used for the same purpose'. Atkinson (1942: 130) described the process of manufacture as follows. 'A slab of stone having been procured and cut to the approximate width of a Roman foot, parallel grooves were cut about 1 inch apart on each side sufficiently deep to allow the bars to be successively snapped off by a sharp blow, and the rough broken surface was then rubbed smooth.' This way of making the bars may be contrasted with that described from the early Roman fort at Usk in South Wales (Manning 1995) and the Gallo-Roman workshop at Buizingen in North Gaul (Thiébaux et al 2012). The cutting at these places was done with a mason's point, yielding ragged, V-shaped grooves and sloping rebates. This way of shaping a whetstone is also known from Strageath (Frere \& Roe 1989: 187, 189, 191), although multiple bars comparable to the Wroxeter examples were probably not made at this central Scottish site.

\section{DISTRIBUTION}

Whetstones of the same provenance as the Newstead find are widely recorded in Roman Britain (Illus 1B), from Wroxeter, Uley, and Ilchester in the west, to Dorchester, Silchester and Fishbourne in the south, to London, Boreham, Scole, Fiskerton, York and Corbridge in the east and north (Allen 2014: figs 7.21, 7.22). This distribution, of 44 sites, is based on material personally examined in thin-section under the petrographic microscope (Allen 2014: 39-43; Allen 2015a), and all available published site descriptions, many including thin-section work, of a sufficient detail and quality as to 
be sure of a Wealden attribution (Allen 2014: Gazetteer, 109-18). The whetstones are also attested from at least two locations, one coastal, the other inland, in north-west Europe (Reniere \& Thiébaux pers comm, 2016). The Trimontium whetstone is - so far - the northernmost example in the known national distribution of these artefacts, which appeared in the 1st century $\mathrm{AD}$ and are known as late as the 4th. Atkinson (1942: 130) was right to attribute them to a 'large and widespread business'. Unfortunately, the precise site of manufacture remains unidentified, but all the geological evidence points to somewhere in the north-west Weald in south-east England (Allen \& Scott 2014). In terms of their dispersal, however, by sea as well as road, as hinted at by the cluster around the Humber estuary, they seem to have been marketed from London, probably by an agent (Allen 2015b). Many were recorded from here in a dockside context (Rhodes 1986), although some of these items appear to have been used. Were the whetstones perhaps manufactured in London, from stone imported from the Weald? The finds from north-west Europe may record long distance trade, but could equally be evidence of the movement of people, especially of the military and administrative classes, carrying with them their personal property as they took up new posts. The spread of the Wealden whetstones

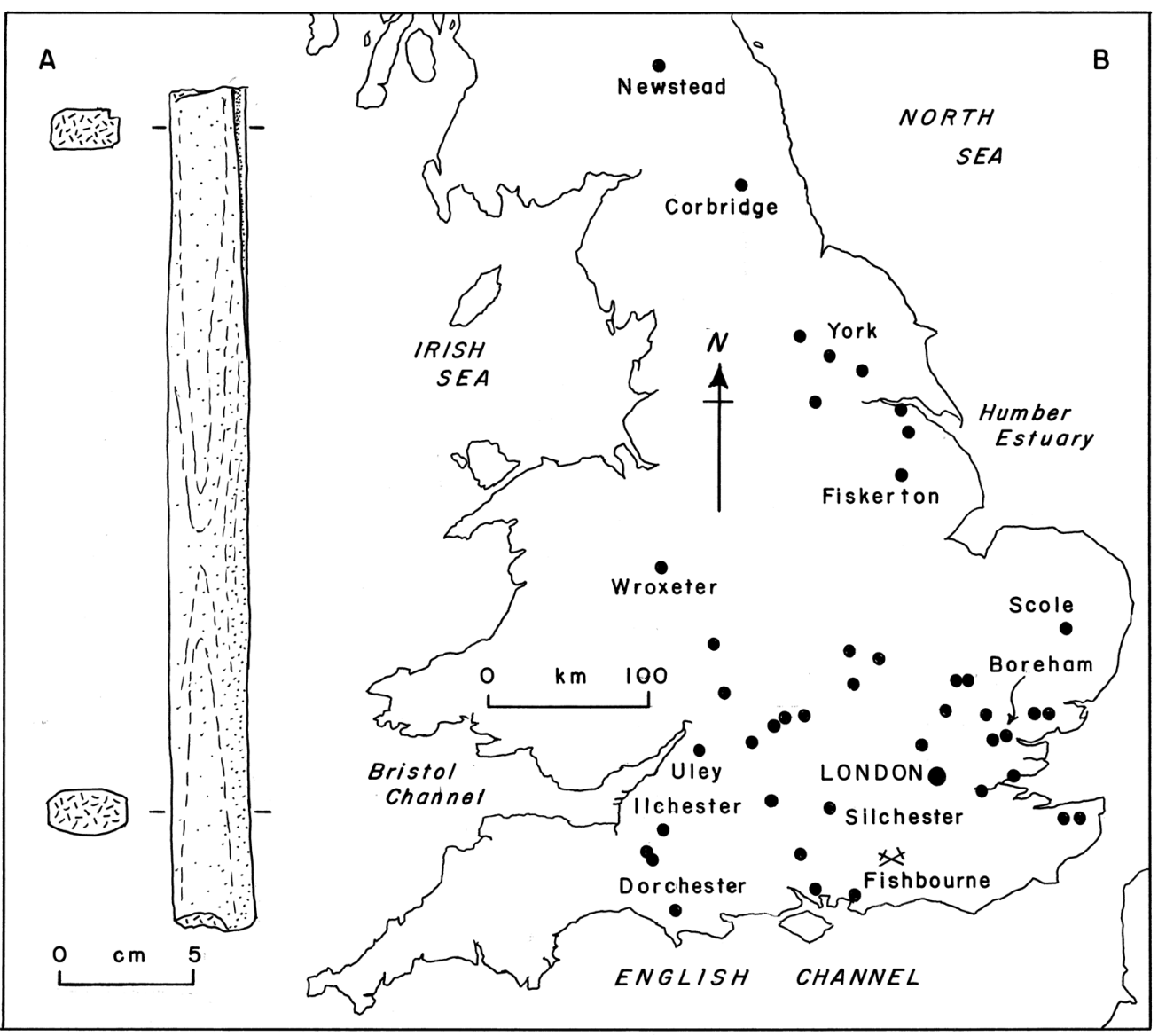

ILlus 1 The Newstead whetstone. A: Appearance. B: Recorded findspots in Roman Britain of whetstones originating in the north-west Weald, south-east England (see text for details of sources) 
therefore compares with that of some other long ranging Romano-British items of everyday use, for example, coarse pottery such as South-east Devon Black-Burnished Ware No. 1 (Allen \& Fulford 1996), recorded from sites in Gaul.

Illustration $1 \mathrm{~B}$ is a conventional findspot distribution map, but there are other techniques of spatial analysis applicable to the dispersal of the Wealden whetstones. One of these is to quantify the changing areal density of the findspots with respect to London, the apparent centre of marketing. This was done by drawing on the distribution a series of concentric circles $50 \mathrm{~km}$ apart, centred on London. These circles define a sequence of rings or bands, each of which embraces a certain portion of the land mass of Roman Britain. The number of findspots contained in each band is then counted and divided by the area of the land mass contained in the ring, yielding an average areal density, conveniently expressed as the number of sites per $10 \mathrm{~km}$ square. This method of spatial analysis has more appeal than methods commonly applied to pottery distributions (eg Fulford \&
Hodder 1974), which make use of percentage abundances, necessarily subject to the limitations of finite number systems.

Illustration 2 shows how the site density varies with radial distance from London, the horizontal scale being arithmetical but the vertical scale logarithmic (only the choice of London minimises the variance in the graph, Corbridge and Newstead excluded). The trend is linear, sloping down to the right, and follows the (exponential) law of natural decay; it breaks down only at the greatest distances from London (Corbridge, Newstead) where only single sites are reported (findspots $(n=44)$ are recorded as integers and cannot by their nature be fractional). The intercept on the vertical axis is a measure of the scale or 'strength' of the source of the artefacts, while the slope is inversely related to the level of appeal of the whetstones in the market, that is, to the 'fluidity' of the product. The distribution can also be characterised by a constant 'half-distance', that is, the radial distance over which the site density diminishes by one half. Does this imply that, in the face of

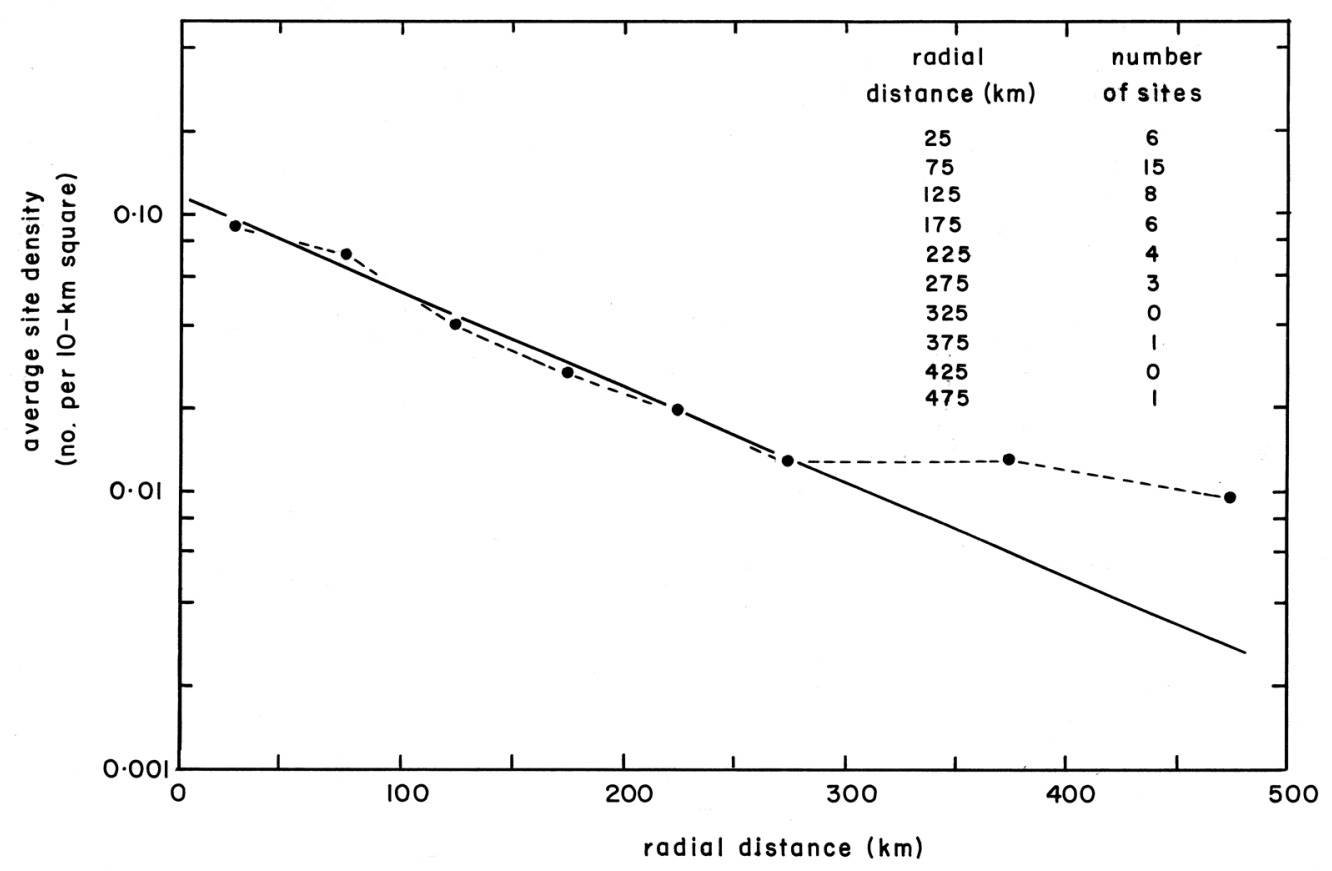

ILLus 2 The negative exponential spatial distribution of the findspots of Wealden whetstones mapped in Illus 1B 
local competition, a constant proportion of the whetstones that reached places could have been retained there for use?

It can be argued instead that Wroxeter and not London was the marketing centre, on the grounds that it has yielded the largest known number of the whetstones. One telling objection is that Wroxeter lies on the western edge of the known national distribution and lacks satellite sites. Wroxeter nevertheless received, on at least one occasion, a significant consignment of the whetstones ( $c$ 100) - a rare 'pre-use' artefact assemblage - ready to be sold or distributed onward (Atkinson 1942).

Similar patterns of negative exponential decline to that portrayed in Illus 2 have been noted for other Romano-British rock-based industries, so far in southern Britain (Allen 2015a), namely, rotary querns of Devonian Upper Old Red Sandstone (Shaffrey 2006), small items of Upper Jurassic Purbeck Marble (Allen et al 2007) and rotary querns of Lower Cretaceous Lodsworth Rock (Shaffrey \& Roe 2011). Exponential decline is not limited to rock-based industries. In the single case to which the method has so far been applied - the dispersal of Young's (1977) late Roman Oxfordshire mortaria - an exceptionally strong trend is seen.

\section{OTHER SCOTTISH BORDER WHETSTONES}

Another carefully manufactured whetstone from Newstead deserves comment. SF FRA 3327, from an Antonine context, Curle's (1911) Pit LXXX, is a fragment (L: $55 \mathrm{~mm}$; W: $27 \mathrm{~mm}$; Th: $20 \mathrm{~mm}$ ) from a worn, bar-shaped whetstone preserving a single, rectangular, longitudinal rebate. Although an item manufactured in a similar way, it is nonetheless lithologically distinct from SF FRA 319 described above. The rock in its case is a compact, pale brown, fine-grained, quartzitic quartz sandstone with scattered mica, apparently unlike that Frere and Roe (1989) described from some whetstones at Strageath to the north-west. The rock is non-calcareous.

A pale brown, quartzitic, quartz sandstone, in this case medium-grained, was used to make SF
FRB 596 from the Mumrills fort on the Antonine Wall (Macdonald \& Curle 1929; Robinson 1979). A substantial but much worn fragment from a bar-shaped whetstone, this item measures L: $151 \mathrm{~mm}$; W: $29 \mathrm{~mm}$; Th: $20 \mathrm{~mm}$ but preserves no longitudinal rebates. A different fine- to medium-grained, quartzitic sandstone was used to fashion SF452 from the mid-2nd-century phase 2 (military) midden in the Roman civil settlement at Inveresk, on the coast east of Edinburgh (Bishop 2004: 159). This broken, bar-shaped fragment has a well-defined, rectangular rebate along each long edge and measures L: $65 \mathrm{~mm}$; W: $22 \mathrm{~m}$; Th: $15 \mathrm{~mm}$. The rock, similar to SF3327 from Newstead, is compact and cemented by secondary silica, but shows two small, pelecypod valves in poor mouldic preservation. It is clearly a manufactured piece.

The brown sandstones used for these three manufactured whetstones are not identical, but could all be from regional Devonian/ Carboniferous sources in the Borders and Midlands.

\section{CONCLUDING DISCUSSION}

In Roman Britain every household, farmstead, workshop and military garrison needed whetstones in order to maintain the sharpness of edged tools and implements. Published site reports suggest that most whetstones used were of the 'found' variety. Some, however, at the high end of the market, were carefully manufactured, and it is to this class that the whetstone of Wealden sandstone from Newstead belongs. The wide dispersal of these whetstones (Illus 1B, 2) is a testament to their quality and appeal, and to a general need. It is not surprising to find that they are represented at almost every kind of Roman site (Allen 2014: Gazetteer, 109-18), including ritual ones (eg Fiskerton, Uley).

Why should long, bar-shaped whetstones be apparently so desirable? The rock used for the Wealden whetstones is not only eminently suited to this purpose in terms of its grain-size and composition (see Allen 2014: 2-3), but the form ensures that the fingers are protected when large blades are being sharpened using the bars. 
Whetstones of the 'found' sort may not be as suitable lithologically (too coarse-grained?) and, because of their general shortness, cannot be used as safely.

How was the Newstead whetstone used? The length and form suggests that it was handheld and applied to sharpen long blades, such as the swords of the military or the scythes and billhooks of a farmer, by means of a repeated back-and-forth motion. The tool seems to have normally been held by the thinner and narrower end, because of the surviving traces of rebates at this position, rather than by the more worn but slightly stouter part. It could therefore have been the prized possession of a single owner. Further evidence that these items were valued and valuable comes from Fiskerton (Field \& Parker Pearson 2003), where four examples, two little-worn and almost complete, occur in a votive context.

The Roman whetstones of Wealden origin discussed above are the first in Britain to be explored systematically on a national basis using the traditional geological technique of thin-section analysis, a method that has been successfully and widely applied to querns and mills (eg Shaffrey 2006; Reniere et al 2016). The survey has illuminated a humble artefact - but one that is the product of a considerable industry - of wide and popular appeal to many different elements in Roman society.

The other whetstones reported above from the National Museum of Scotland suggest that the Wealden industry may not have been alone but in competition with others manufacturing to a similarly high standard, but on geological evidence, based in northern Britain. These shadowy, previously unrecognised enterprises merit wider investigation. In this work for the future, the thin-section method is likely to prove superior to the use of non-invasive techniques, such as pXRF, which, although favoured by many curators and funding bodies, yield results that are difficult to interpret and seldom critical.

\section{ACKNOWLEDGEMENTS}

I am indebted to my colleague Professor Michael Fulford (University of Reading) for drawing my attention to the Newstead whetstone, and to Dr Fraser Hunter (National Museums Scotland, Edinburgh) for his interest and advice, and for generously facilitating my examination and analysis of the artefact and its associates. Dr Simon Howard of the Museums kindly provided additional lithological information.

\section{REFERENCES}

Allen, J R L 2014 Whetstones from Roman Silchester (Calleva Atrebatum), North Hampshire. Character, Manufacture, Provenance and Use. Oxford: British Archaeological Reports, British Series, 597.

Allen, J R L 2015a 'Exponential decline in the dispersal of stone artefacts in Roman Britain: further expressions of trade', Oxford Journal of Archaeology 34: 97-108.

Allen, J R L 2015b 'A whetstone of Wealden sandstone from the Roman villa at Great Holts Farm, Boreham, Essex', Britannia 46: 247-51.

Allen, J R L \& Fulford, M G 1996 'The Distribution of South-East Dorset Black Burnished Category 1 Pottery in South-West Britain', Britannia 27: 223-81.

Allen, J R L, Fulford, M G \& Todd, J A 2007 ‘Burnt Kimmeridgian shale at early Roman Silchester, south-east England, and the Roman PoolePurbeck Complex Agglomerated Geomaterials Industry', Oxford Journal of Archaeology 26: 167-91.

Allen, J R L \& Scott, A C 2014 (for 2012) 'The whetstone blanks from the forum-basilica at Roman Wroxeter: the case for provenance', Transactions of the Shropshire Historical and Archaeological Society 87: 1-12.

Atkinson, D 1942 'The finds in the east portico gutter', in Atkinson, D Report on Excavations at Wroxeter (the Roman City of Uriconium) in the County of Salop, 128-30. Birmingham: Birmingham Archaeological Society.

Bishop, M C 2004 Inveresk Gate: Excavations in the Civil Settlement at Inveresk, East Lothian. Edinburgh: Scottish Trust for Archaeological Research.

Curle, J 1911 Newstead. A Roman Frontier Post and its People. Glasgow: Maclehose for The Society of Antiquaries of Scotland. 
Field, N \& Parker Pearson, M 2003 An Iron Age Timber Causeway with Iron Age and Roman Votive Offerings. Oxford: Oxbow Books.

Frere, S \& Roe, F 1989 'Other objects in stone', in Frere, S S \& Wilkes, J J (eds) Strageath. Excavations within the Roman fort 1973-1986, 187-91. London: Society for the Promotion of Roman Studies, Britannia Monograph Series No. 9.

Fulford, M H \& Hodder, I R 1974 'A regression analysis of some late Romano-British fine pottery: a case study', Oxoniensia 39: 26-33.

Hunter, F \& Keppie, L 2012 A Roman Frontier Post and its People. Newstead 19112011. Edinburgh: National Museums of Scotland.

Macdonald, G \& Curle, J O 1929 'The Roman Fort at Mumrills near Falkirk', Proc Soc Antiq Scot 63: 396-575.

Manning, W H 1995 'Honestones', in Manning, W H (ed.) Report on the Excavations at Usk 1965-1976. The Roman Small Finds, 257-26. Cardiff: University of Wales Press.

Reniere, S, Dreesen, R, Fronteau, G, Gluhak, T, Goemaere, É, Hartoch, E, Picavet, P \& De Clercq, W 2016 'Querns and mills during Roman times at the northern frontier of the Roman Empire (Belgium, Northern France, Southern Netherlands, Western Germany): Unraveling geological and geographical provenances, a multidisciplinary research project', Journal of Lithic Studies 3: 403-28.

Rhodes, M 1986 'Stone objects', in Miller, L, Schofield, J \& Rhodes, $\mathrm{M}$ (eds) The
Roman Quay at St Magnus House, London, 240-3. London: London and Middlesex Archaeological Society, Special Paper 8.

Robinson, A S 1979 The Antonine Wall: A Handbook to the Roman Wall Between Forth and Clyde and a Guide to its Surviving Remains. Glasgow: Glasgow Archaeological Society.

Shaffrey, R 2006 Grinding and Milling. A Study of Romano-British Rotary Querns and Millstones made from Old Red Sandstone. Oxford: British Archaeological Reports, British Series, 409.

Shaffrey, R \& Allen, J R L 2014 'A complete whetstone of Wealden origin from the Roman site at Tackley, Oxfordshire', Britannia 45: 288-93.

Shaffrey, R \& Roe, F 2011 'The widening uses of Lodsworth stone: Neolithic to RomanoBritish quern distribution', in Williams, D \& Peacock, D P S (eds) Bread for the People: the Archaeology of Mills and Milling, 30924. Oxford: British Archaeological Reports, International Series, 2274.

Thiébaux, A, Goemaere, É \& Herbosch, A 2012 'Un atelier gallo-romain de pierres à aiguiser découvert à Buizingen (Hal, Belgique): reconstitution des étapes de fabrication et détermination des origines géologiques et géographiques du matériau', Revue du Nord 398: 143-57.

Young, C 1977 The Roman Pottery Industry of the Oxford Region. Oxford: British Archaeological Reports, British Series, 43. 
